\title{
Feminist Issues and the Popularity of Feminist Literature in the World and Vietnam
}

\author{
Le Thi Thanh Xuan \\ Department of Vietnamese Studies, The University of Foreign Languages, Hue University, Vietnam
}

\begin{abstract}
Currently, feminism and feminist movements seem to have become "popular" and is extremely in favor of all aspects of social life. Especially in the field of literature, the trend of feminist research shows that the need for equality and charity as well as the fight for gender equality is becoming more and more urgent both in the world and Vietnam. This is a large and in-depth research topic, but with the limited volume of the article, the author only mentions feminism issues, feminist theory as well as the popularity of feminist literature. At present time comparing and contrasting feminist literature in the world as well as in Vietnam so far. Since then, it is clear that the value of feminist literature and the popularity of feminist literature is an inevitable development in the current gender equality trend.
\end{abstract}

KEYWORDS: Equality, Feminism, Literature, Trends, Theory.

\section{INTRODUCTION}

Feminist literary criticism has traditionally been seen as a valuable critical research trend and has been popular in the West ever since. Along with the development of feminist theory, articles, research articles and literary criticisms on feminism have clearly shown the top concerns of scholars, critics, and researchers around the world. That is the issue of gender equality today. This author has focused on researching and analyzing the main issues enhanced on critique such as introduction to feminism and feminist theory as well as the popularity of feminist literature in the world and Vietnam. From that, it can be seen that the new step is similarity in promoting the feminist sound in literature in the West and Vietnam, full of strength and diversity in expression although the culture of each nation is different. That proves the importance of feminist theory and feminist literary criticism as the foundational premise, as the basis for the development of later feminist literature in many different forms and genres.

\section{FEMINIST ISSUES AND FEMINIST THEORY}

\subsection{Feminist issues - origins and concepts}

"Feminism" was provoked by Charles Fourier, a French philosopher specializing in utopian socialism. The term "feminism" or "feminist" first appeared in France and the Netherlands in 1872, in Great Britain in the 1890s, and in the United States in 1910. The Oxford English Dictionary first introduced the word "feminist" in 1894, where feminist is translated as "feminist". Feminist movements appeared mainly to demand legitimate and fair rights for women.

As can be seen, the term "feminist" can be understood through the following aspects:

- In terms of theory: feminism is considered as a theoretical premise to fight for the equality of women.

- In terms of practical activities: the feminist movement plays an important role in gaining women's rights in political and economic aspects, especially in protecting and referring to basic human rights.

- From a professional perspective: feminism struggles towards the goals of equality between men and women (gender equality) in social, corporate and individual professional activities.

In short, the concept of "feminism" is always associated with gender consciousness and gender equality, gender identity and some other basic rights. Since the movement for women's rights appeared, women have become more self-conscious about their gender. Gender consciousness is concerned, spreading more widely in society and women themselves have become aware of their rights. This status because has throughout "referred to a lot in terms of sociology, stemming from efforts to bring about gender equality and protect women against social prejudices and traditional notions that despise women, defaulting to women being weaker than men" [6, p.279] . It forms the struggle of women, gender equality is expressed through many diverse "channels" differently and achieve a positive effect: protest, meetings, books, literature... Women are gradually overcoming themselves in many ways and that proves that the fight for women's rights is the most typical fight for human dignity. 


\section{International Journal of Current Science Research and Review}

ISSN: 2581-8341

Volume 04 Issue 09 September 2021

DOI: 10.47191/ijcsrr/V4-i9-16, Impact Factor: 5.825

\subsection{Some issues about feminist theory}

Theory gender / feminist theory is recognized as the awareness and curb oppression, exploitation, abuse of women at work, in social life and family life. At the same time, move towards a complete end to patriarchal domination, oppression and exploitation of women's sexual and reproductive health. And the right to speak up to contribute, be treated equally with men in every job and relationship status.

Also, feminism or secularist women are a compilation of the feminist movement to protect the rights and equality of women in political, economic, social, cultural ... In particular, giving priority to education and employment issues for women. The theoretical system of feminism was born as a complete rejection of the subjective, scientifically imposed theories of men. For example, the feminists Lacan and Derrida were completely convinced by the post-structural theory they proposed because "they actually refused to confirm the authority or truth "masculine"[7].

Importantly, Le Deuxième Sexe (The second sex) (1949) by Simone de Beauvoir pointed out the inequality even in the terms "masculine" and "feminine". That is why "Women are made underlings and oppression is compounded by men's belief that women are underdogs by nature" [96]. Both Beauvoir and Virginia Woolf acknowledge the limited influence of biological and sex origin on this inequality. The work Le Deuxième Sexe "is imbued" with feminism and existentialism with the statement that carries the manifest value of feminist theory: "The attitude towards freedom is the highest value of human beings, which is a measre of ethics and their unethical man himself " [6].

According to Beauvoir, women must realize that they are not an "other", independent of the "me" of men, in order to realize gender equality. Beauvoir's quote has "change the fate of hundreds of milions of people": "One is not born a woman, but becomes a woman". And Virginia in her work A room of one's own (1929) pointed out that the dependence of women is economic, according to her, if a woman has economic independence, she can create her own happiness. She famously said: "If a woman writes, she must have money and a room of her own". The work A room of one's own has become a "phenomenon" because it pioneered feminist criticism in literature. As a result, the feminist movements have spread more widely around the world, it is called the "cultural turn" or "feminist turn" by the change, the process of movement and develpoment in a positive direction in human thought. And so, feminist theory is "the struggle for women's freedom and equality, demanding to open up a larger social space for women to be involved, redefining women, deconstructing stereotyped symbols of women that dominate social perception" [2].

On discussing feminism, the issue of power cannot be ignored. Power is understood as "the ability to act and influence" an individual or a group of people in society. Or simply understood according to the concept of feminists, "power as domination, including oppression, male domination or submission. They especially emphasize the power imbalance between men and women" $[1]$.

The problem of power stems away the imbalance of social status and position in the family of women, in which, men always have the advantage of power over women. The man in the family is always assumed to be the "strong man", "the breadwinner", on the contrary, the woman palys the role of "the weak", "the dependent", nor "the slave". Feminists all have their own split concept of dominance. Socialist feminists view the issue of power as stemming from masculinity and nepotism. It can be said: "This oppression is manifested in five aspects: economic exploitation, isolation from socio-economic development, lack of autonomy, cultural hegemony, and systematic violence (Young, 1992)" [3].

While socialist feminists see the source of the problem of power as male rule, poststructural feminists found the issue of perspective submission according to M. Foulcault's conception of power. Some other feminist consider "power as the ability to do a thing or a choice or power as power as empowerment". Concepts of power are diverse. According to feminists, it is not really domination, but it is also a way to express authority, ego, or in other words, the hidden personal power of women: "Women want to have rights. power in a way that simultaneously enhances, but does not limit, the power of others (Miller, 1992)” [3].

\section{THE POPULARITY OF FEMINIST LITERATURE IN THE WORLD AND VIETNAM}

Feminist works are famous for their meaningful value as well as practical application of feminism in economic, political, social, scientific, legal aspects... and its influence worldwide can be mentioned here: Le Deuxième Sexe (1949) by Simone de Beauvoir, The Feminine Mystique (1963) by Betty Friedan, Thinking about Women (1968) by Mary Ellmann, A Room of One's Own (1929) ) by Virginia Woolf, Sexual Politics (1970) by Kate Millet, Everyone was Brave (1971) by William O'Neil, The Dialectic of Sex (1970) by Shulamith Firestone, The Laugh of the Medusa (1976) by Helene Cixous, This Sex which is not One (1977) by Luce 


\title{
International Journal of Current Science Research and Review
}

\author{
ISSN: 2581-8341
}

\section{Volume 04 Issue 09 September 2021}

DOI: 10.47191/ijcsrr/V4-i9-16, Impact Factor: 5.825

Irigaray... Thus, it can be seen that feminists and their doctrines have positively influenced the birth and rich development of feminist literary criticism as well as feminist literary genres in the world later.

Following the foundational values of feminist theory of previous authors, feminist literature in the world as well in the West has achieved remarkable results. It's the result of quantity on foreign literary works with the main image of women as well as defending and fighting for the status of small and unhappy women in modern society. At the same time, proving that women "deserve more" with all their efforts in society. Respect and recognition of the role of women in all aspects of society is what critics, scholars, researchers and writers around the world aim and fully express their multi - dimensional views in each of their works. The number of diverse and rich works revolving around the image of women in Western literature has demonstrated "the struggle for women's freedom and equality, demanding the opening of a social space a broader society for women to be involved, redefining women, and deconstructing stereotyped symbols of women that dominate social perception" [2].

"For Western feminist literature, female writers have created a buzz with valuable works along with strong voices in support of and advocate for women's rights in society, equal scope gender is established by the power of words" and "l'écriture feminine". Some typical female authors for contemporary Western literature can be mentioned as Magda Szabó, Margaret Atwood, Louise L.Hay, Marie Ndiaye, Marguerite Duras...

Magda Szabó - famous Hungarian novelist with well respect novels on the topic of the psychological world of modern women such as The Fawn (1959), Iza's Ballad (1963), Abigel (1970) is an adventure, the commitment of a young Hungarian girl during World War II... And especially, the work The door (1987) is Magda Szabó's most famous work, which has been translated into dozens of different languages. Clearly depicting the surrounding psychology around the relationship between two women. One is a writer and a woman sweeping the trash, but the strange mystery from her strong, decisive, unwavering and upright personality, always staying true to herself has touched the hearts of millions of readers around the world.

Living in a country with unstable politics like Pakistan, author Malala Yousafzai has inspired many teenagers and young generations with the desire to live, study and contribute from a very young age. The author Malala's autobiography I'am Malala has shown a strong feminist struggle, demanding the right to go to school of a girl only 10 years old regardless the draconian views of the Muslim society towards women. Despite being fatally shot by the Taliban, she miraculously survived and still fought for the ideal of schooling for Pakistan children. The voice of a young girl who defies the boundaries of life and death has created a sensation that spreads in the hearts of those who love peace and hate war all over the world. Malala's struggle has given the world a common voice in protecting girls' rights: to go to school and have a warm, happy childhood.

Author Margaret Eleanor Atwood with the famous feminist novel The Handmaid's Tale has lifted a curtain of horror with the ultimate feelings of pain, loss, and mourning for women. Through the brutal truth that women at the bottom of society have to endure is a strong feminist voice wishing to be freed from the bleak fate of giving birth to the families of the Commander who lost their fertility. They are looked down upon and mistreated, using their motherhood to the point of exhaustion, and when it's "out of date", they are mercilessly discarded and chased away.

Especially here in Vietnam, the situation of feminist research and the popularity of feminist literature has developed premature, right from the early years of the twentieth century. Among the researchers on women's liberation issues of Phan Khoi, Phan Thi Bach Van, Huynh Thi Bao Hoa, Nguyen Thi Manh Manh... According to the modernist trend of approaching feminist literature, there have been a number of articles analyzing the resonance of feminism / feminist theory / methodical feminist literary criticism. Many outstanding achievements such as "Gender consciousness in contemporary female prose" by Nguyen Thi Binh; "The way to legitimize feminist theory - feminist literary criticism" by Dang Thi Thai Ha; "On the wave of feminism and its influence on the status of Vietnamese women" by Hoang Ba Thinh; "The movement of literary genres in the renovation period" by Ly Hoai Thu... The authors have introduced, analyzed and explained the path of formation, importance and inevitable movement of the theory of feminist criticism applied to Vietnamese literature by many various genres such as literary theory, poetry, short stories, novels... Although the number of research works is not much, in general, the articles have a comprehensive view of the theory of feminist criticism, helping to raise the status and concern for the rights of Vietnamese women, which are vividly and subtly expressed in literature.

In the field of short stories, Vietnamese female writers have shown their strengths, especially from 1986 onwards with many "branded" works such as Cánh đồng bất tận (The Endless Field) by Nguyen Ngoc Tu, I'm đàn bà (I'am a woman) by Y Ban, Bóng đè (The shadow of sleep) by Do Hoang Dieu, Búc thu gủi mẹ Âu Co' (A letter to Au Co's mother) by Y Ban, Hoa vông vang (Vong 


\title{
International Journal of Current Science Research and Review
}

ISSN: 2581-8341

\author{
Volume 04 Issue 09 September 2021
}

DOI: 10.47191/ijcsrr/V4-i9-16, Impact Factor: 5.825

vang flowers) by Ho Thi Hai Au, Trăng nơ đáy giếng (The moon at well's bottom) by Tran Thuy Mai... has affirmed the position of women in the country's literature. In the realm of novels, there is an affirmation of the female world's position with the development of many quality works by female authors who resonate such as Gia đình bé mọn (Little Family) by Da Ngan, Thế giới xô lệch (Distorted World) by Bich Ngan, Blogger by Doan Le, Trong nước giá lạnh (In frozen water) by Vo Thi Xuan Ha, Nhân gian (Human World) by Thuy Duong, Tiểu thuyết đàn bà (Women Novel) by Ly Lan...

Although the works of female writers mostly reflect the tragedy of women, on the contrary, it is not so tragic that it integrates the spirit of "immortality", potential vitality of "flowers" that have been "buried", "tattered" but still give off the fragrance of life. That is the beautiful "female divinity" of women with compassion full of humanity such as the lamp that does not go out, the end of the season of beauty, Cánh đồng bất tận (The Endless Field) by Nguyen Ngoc Tu; The ups and downs of life, the moments apart from husband and wife, the longing for love of unfortunate women suddenly help them realize that the family value is still eternal: Nhà có ba chị em (There are three sister at home) by Vo Thi Xuan Ha, Rượ cúc, Biển ấm (Chrysanthemum wine, Warm Sea) by Nguyen Thi Thu Hue, Ngôi đền sống (Living Temple) by Tran Thuy Mai; the struggle for the "me" of the person, to find the ego, to change fate: Sau chóp là giông bão (A storm coming after lightning) by Y Ban, Thập tụ hoa (Flower cross) by Tran Thuy Mai, Lưa trên sông (A fire on a river) by Nhu Binh, Huyền thoại cỏ mặt trời (A legend of Sun grass) by Tran Thanh Ha, Làn môi đồng trinh (Virgin lips) by Vo Thi Hao.

Whether it's short stories or novels, the works of this period are all about women with life's upheavals and the main authors are female writers with experience of suffering, bitterness, happiness. Female writers have really created a highlight with loving ontological feelings because they are simply insiders and they understand the sense of feminism. Gender awareness from their own gender better than anyone else. That shows the diversity and strong "renovation" of Vietnamese literature in the national renewal period, because most of the works "advance the role of women in the family and society, and at the same time, promote the role of women in the family and society, reflects the low status of women as well as the aspiration for equality and the spirit of resistance of Vietnamese women" [4].

\section{CONCLUSION}

The problems analyzed and clarified above on the emergence and popularity of feminism throughout the development of feminist movements, the number of research works on theory as well as literature on feminism are somewhat "limited" and "younger" than the West as it is in Vietnam. It is also understandable, because Western literature is the premise and foundation on issues related to feminism. It is gradually spreading and popularized, deeply affecting Asian countries such as Vietnam, China, Korea, Japan... This proves that women around the world can confidently change their own unhappy fate with aspiration, passion and dedication to themselves, their family and society. The woman's strong dedication aspirations have shown her extraordinary will to master life, overcome adversity, and affirm her self-worth. With the famous work Le Deuxième Sexe, Beauvoir was convinced: "Women do not ask to be praised for themselves, but they always want to rise high to surpass their inevitable status, not only for themselves but also for the whole of humanity" [5, p.157]. That is also the irresistible "attraction" of literature about women, showing the creativity and humanity of female writers around the world in contemporary literature in which women are the lyrical subjects and creative subjects in feminist books around the world.

\section{REFERENCES}

1. Beasley, Christ (1999), What is Feminism? New York: Sage. ISBN 9780761963356.

2. Tran Ngoc Hieu (2009), “An one own's room introduction”, Source: http:www.chungta.com, 19/10/2009.

3. Pham Thi Hue (2017), "The power of husband and wife in rural Vietnamese families, VietNam - Sociology, volume 03.

4. Hien Nguyen (2014), "Feminist literature in VietNam", Source: http://toquoc.vn, 14/8/2014.

5. Bui Thi Tinh (2010), Women and gender, Nat. Poli. Pub. House, Ha Noi.

6. Phung Gia The, Tran Thien Khanh (2016), Literature and women (Some theoretical and historical issues), World Pub, Ha Noi.

7. Wikipedia, "Feminism", Source: http://vi.m.wikipedia.org, 6/12/2018.

Cite this Article: Le Thi Thanh Xuan (2021). Feminist Issues and the Popularity of Feminist Literature in the World and Vietnam. International Journal of Current Science Research and Review, 4(9), 1189-1192 